\title{
Bacteriophages as Alternatives to Antibiotics in Clinical Care
}

\author{
Danitza Romero-Calle ${ }^{1}$, Raquel Guimarães Benevides ${ }^{1}$, Aristóteles Góes-Neto ${ }^{1}$ and \\ Craig Billington $2, *$ (D) \\ 1 Postgraduate Program in Biotechnology, State University of Feira de Santana (UEFS), \\ Av. Transnordestina S/N, Feira de Santana-BA 44036-900, Brazil \\ 2 Health \& Environment Group, Institute of Environmental Sciences and Research, PO Box 29-181, \\ Christchurch 8540, New Zealand \\ * Correspondence: craig.billington@esr.cri.nz
}

Received: 2 August 2019; Accepted: 3 September 2019; Published: 4 September 2019

\begin{abstract}
Antimicrobial resistance is increasing despite new treatments being employed. With a decrease in the discovery rate of novel antibiotics, this threatens to take humankind back to a "pre-antibiotic era" of clinical care. Bacteriophages (phages) are one of the most promising alternatives to antibiotics for clinical use. Although more than a century of mostly ad-hoc phage therapy has involved substantial clinical experimentation, a lack of both regulatory guidance standards and effective execution of clinical trials has meant that therapy for infectious bacterial diseases has yet to be widely adopted. However, several recent case studies and clinical trials show promise in addressing these concerns. With the antibiotic resistance crisis and urgent search for alternative clinical treatments for bacterial infections, phage therapy may soon fulfill its long-held promise. This review reports on the applications of phage therapy for various infectious diseases, phage pharmacology, immunological responses to phages, legal concerns, and the potential benefits and disadvantages of this novel treatment.
\end{abstract}

Keywords: bacteriophages; clinical trials; antibiotic resistance; infectious disease; phage therapy

\section{Introduction}

There are approximately $10^{30-31}$ bacteriophages (phages) in the biosphere [1,2], which is estimated to be 10-fold higher than the total number of bacterial cells [3]. Phages are also an inherent part of the human microbiome, and so are usually well-tolerated when used in phage therapy [4-6]. Phages are one of the most promising alternatives to antibiotics, which can be used for medicine, agriculture, and related fields [7]. The evolution of multidrug-resistant and pan-drug-resistant bacteria poses a real threat to the control of infectious diseases globally, so it is urgent to have new therapeutic tools available. The United States National Institutes of Health have stated that phages are promising tools for combatting microbial resistance [8].

A post-antibiotic era in which minor injuries and common infections can kill because of the lack of drugs or their ineffectiveness is nowadays not an apocalyptic fantasy, but a real 21st-century threat. For example, ESKAPE organisms (Enterococcus faecium, Staphylococcus aureus, Klebsiella pneumoniae, Acinetobacter baumannii, Pseudomonas aeruginosa, and Enterobacter spp.) are extremely resistant to multiple antimicrobial agents [9] and are a serious challenge in medicine today. On the other hand, there historically has been no fit for purpose regulatory framework to deal with novel flexible and sustainable therapeutic approaches such as phages. For phages, this includes oversight of the setup and approval of adequate clinical trials, so as a result, there is no standard protocol for phage therapy.

In this review, we summarize the phage therapy clinical trials that have shown promising results in patients. We cover several diseases, immunological responses to phages, phage pharmacology, legal 
concerns about phage therapy, phage genetic modification, and a description of the advantages and disadvantages of phage therapy when compared to conventional treatments with antibiotics.

\section{Phage Biology}

Viruses that infect bacteria and Achaea are called phages, which have no machinery for generating energy and no ribosomes for making proteins. They are obligate bacterial parasites that carry all the genetic information required to undertake their reproduction in an appropriate host. The genome size of phages varies from a few thousand base pairs up to 498 kilobase pairs in phage G, which is the largest phage sequenced to date [10]. Most phages have a high level of host specificity (though some are broad in range), high durability in natural systems, and the inherent potential to reproduce rapidly in an appropriate host. They can be found associated with a great diversity of bacterial species in any natural ecosystem [11].

Phages can be characterized by their size and shape into three general groups: icosahedron, filamentous, and complex. Members of these groups may contain nucleic acid of various types including single-stranded DNA (ssDNA), double-stranded DNA (dsDNA), single-stranded RNA (ssRNA), or double-stranded RNA (dsRNA). Phages can be further classified with respect to their actions that follow infection of the bacterial cell. Virulent bacteriophages reproduce immediately and induce lysis of the cell to enable progeny release, whereas temperate phages insert their genetic material into the host genome or accessory elements, where they reproduce with the host until triggered to enter the lytic pathway as observed for virulent phages [12].

Virulent tailed phages of the Caudovirales order have been the best described for phage therapeutic applications. Within this group, the Myoviridae have a large capsid head and contractile tail, the Siphoviridae have a relatively small capsid and a long flexible non-contractile tail, and the Podoviridae have a small capsid head and short tail [13]. The virulent tailed phages follow a lytic cycle that begins with the specific attachment of phage anti-receptors to host cell surface receptor molecules. This interaction is often two-step, with an initial reversible phase and then irreversible phase. Once irreversibly bound, enzymes degrade the cell wall and the genetic material is ejected into the cell with (usually) the assistance of processive host enzymes. Once transcribed, the phage genome begins to redirect the host cell metabolism including DNA replication and protein biosynthesis to the reproduction of viral nucleic acid and proteins. Often, the host genome is degraded during this process. Once complete daughter viral particles are assembled, cell lysis is initiated to release the particles. Bacterial lysis is triggered by late encoded phage proteins including holins (to permeabilize the inner cell membrane) and endolysins (to degrade the peptidoglycan) with the loss of cell wall integrity causing lysis due to osmotic differential [14].

\section{Specificity}

Host specificity (range) of phages is variable, with some phages infecting multiple species and others only growing on one known isolate. However, their specificity is much higher than that of antibiotics. The phage host cell surface receptors and antiviral defense mechanisms (genetic and physical) are the main properties that determine specificity. For some highly conserved species, a single phage can kill the majority of strains (e.g., phage P100 infects $>90 \%$ Listeria monocytogenes isolates tested [15]). Phages that propagate on species with high clonal diversity (e.g., Pseudomonas aeruginosa) typically only kill a small cohort of strains [16].

Establishment of phage banks or training (in vitro evolution) of phages to become more active and to elicit less bacterial resistance against the infecting bacterial strain can be valid strategies to overcome limited host specificity for targeted phage therapy [16]. This strategy likely works best for chronic infections where the target bacterium is well characterized. In order to treat acute infections, phage cocktails including phages that together span the whole spectrum of potential strains are proposed. However, the research and resources needed for the production of suitable and stable multi-component cocktails are disadvantages of this approach. An alternative approach is to use phage lytic enzymes 
(endolysins), which show broader host specificity at the genus and species level. Endolysins have been the subject of a recent review by our group [17], so are not discussed further here.

Antibiotics typically kill a broad-spectrum of either Gram-positive and Gram-negative bacteria including benign flora, which is increasingly considered to be non-desirable due to their adverse effects on the whole microbiota and potential to spread antibiotic resistance $[18,19]$. Phage therapy meets these challenges by its superior specificity and ability to treat drug-resistant isolates.

\section{Phage Pharmacology}

The pharmacology of phages necessitates the study of interactions between phages and bacteria as well as interactions between phages and body tissues [14]. Successful and safe phage therapy involves the effective control of phage-host interactions involving two fundamental components: pharmacodynamics and pharmacokinetics [20].

\subsection{Pharmacodynamics}

Pharmacodynamics is the study of the interaction of drugs with their receptors, the transduction systems to which they are related, and the changes in cells, organs, and the whole organism. The drugs' impact on the body can either be positive, thus maintaining or restoring health, or negative such as causing toxic side effects [20].

Phages can be applied via active or passive therapeutic strategies. In active treatment regimes, phages are introduced at low concentrations relative to the bacteria concentration and therapy relies on the production and release of progeny phages to infect all bacteria. Active treatments with phages are considered to have features of automated dosing and to mimic the bodies' homeostatic mechanism better than standard pharmaceuticals through the targeted killing of bacteria and phage production at actual sites of infection rather than systemically [21]. In contrast, passive phage treatment relies on single, or multiple rounds of sufficient phage concentrations to infect all target bacteria.

Compared to antibiotics, only a single phage is required to kill a single bacterium and so fewer units are required per treatment. Phages also do not dissociate from bacterial targets once irreversibly adsorbed. However, multiple phages may adsorb to individual bacteria. For these reasons, it is important to understand the concepts of multiplicity of infection (MOI), which is the ratio of phage infections per bacteria, and MOI input, which is the number of phages that are administered per cell. The killing titer is another concept that can be used to guide phage therapy and is the number of effective bactericidal phage particles delivered (c.f. the number of plaque-based phage counts) [14,20-23]. Failure to recognize the special requirements of phage pharmacodynamics could result in compromises to phage therapy efficacy [20].

The degradation of phages by antibodies and other aspects of the immune system do not lead to the production and accumulation of toxic by-products. The low toxicity of phages is a consequence of their composition which, for tailed phages, is entirely protein and nucleic acid. As a result, phage therapy can be considered comparatively physiologically benign when compared to standard antibiotic therapies.

\subsection{Pharmacokinetics}

Pharmacokinetics describes the absorption, distribution, metabolism, and excretion of a drug. Absorption and distribution of the drug require its movement throughout the body, at first to the blood and then beyond the blood into specific tissues or compartments where the drug may accumulate at different densities [20]. Phage pharmacokinetics are also influenced by decay and proliferation as a result of the self-replication of bacteriophages.

The route of administration for phages will also affect in situ pharmacokinetics. In clinical cases, phages are frequently delivered by parenteral administration with oral dosing, topical application, and aerosolization also common. Data on the relative effectiveness of these approaches is largely drawn from animal studies. For instance, intramuscular, intraperitoneal, and subcutaneous injection of a phage cocktail were compared for efficacy in treating a P. aeruginosa in a murine burn model where 
intraperitoneal injection was found to be the most effective, most likely due to the delivery of higher numbers of phages more quickly and for a greater sustained period than other routes [24]. When using oral phage dosing in mice, the addition of $0.025 \% \mathrm{CaCO}_{3}$ was found to effectively protect the phage from stomach acids and deliver the phage to the upper and lower gastrointestinal tract where they reduced numbers of the targeted E. coli O157:H7 [25]. When treating Burkholderia infections induced in mice, the aerosolization of phages was found to be superior to intraperitoneal injection [26]. Some advantages and disadvantages of the administration routes are shown in Table 1.

Table 1. Routes of administration for phage therapy.

\begin{tabular}{|c|c|c|c|}
\hline Delivery Route & Advantages & Disadvantages & Mitigations to Hurdles \\
\hline Intraperitoneal & $\begin{array}{l}\text { Higher dosage volumes } \\
\text { possible. Diffusion to } \\
\text { other sites. }\end{array}$ & $\begin{array}{l}\text { Extent of diffusion to other sites } \\
\text { may be overestimated in } \\
\text { humans (most data from small } \\
\text { animals). }\end{array}$ & Multiple delivery sites. \\
\hline Intramuscular & $\begin{array}{l}\text { Phages delivered at } \\
\text { infection site. }\end{array}$ & $\begin{array}{l}\text { Slower diffusion of phages } \\
\text { (possibly). } \\
\text { Lower dosage volumes. }\end{array}$ & $\begin{array}{l}\text { Multi-dose courses. } \\
\text { Multi-dose courses. }\end{array}$ \\
\hline Subcutaneous & $\begin{array}{l}\text { Localized and systemic } \\
\text { diffusion. }\end{array}$ & Lower dosage volumes. & Multi-dose courses. \\
\hline Intravenous & Rapid systemic diffusion. & $\begin{array}{l}\text { Rapid clearing of phages by the } \\
\text { immune system. }\end{array}$ & $\begin{array}{l}\text { In vivo selection of } \\
\text { low-immunogenic } \\
\text { phages may be possible. }\end{array}$ \\
\hline Topical & $\begin{array}{l}\text { High dose of phages } \\
\text { delivered at infection } \\
\text { site. }\end{array}$ & $\begin{array}{l}\text { Run-off from target site if } \\
\text { phages suspended in liquid. }\end{array}$ & $\begin{array}{l}\text { Incorporate phages into } \\
\text { gels and dressings. }\end{array}$ \\
\hline Suppository & $\begin{array}{l}\text { Slow, stable release of } \\
\text { phages over long time. }\end{array}$ & $\begin{array}{l}\text { Limited applications/sites. Risk } \\
\text { of insufficient dosing. } \\
\text { Technically challenging to } \\
\text { manufacture. }\end{array}$ & $\begin{array}{l}\text { Careful consideration of } \\
\text { phage kinetics required. }\end{array}$ \\
\hline Oral & $\begin{array}{l}\text { Ease of delivery. Higher } \\
\text { dosage volumes possible. }\end{array}$ & $\begin{array}{l}\text { Stomach acid reduces phage titer. } \\
\text { Non-specific adherence of } \\
\text { phages to stomach contents and } \\
\text { other microflora. }\end{array}$ & $\begin{array}{l}\text { Add calcium carbonate } \\
\text { to buffer } \mathrm{pH} \text {. } \\
\text { Microencapsulation to } \\
\text { deliver phages to target } \\
\text { area. }\end{array}$ \\
\hline Aerosol & $\begin{array}{l}\text { Relative ease of delivery. } \\
\text { Can reach poorly } \\
\text { perfused regions of } \\
\text { infected lungs. }\end{array}$ & $\begin{array}{l}\text { High proportion of phages lost. } \\
\text { Delivery can be impaired by } \\
\text { mucus and biofilms }\end{array}$ & $\begin{array}{l}\text { Use of depolymerases to } \\
\text { reduce mucus. }\end{array}$ \\
\hline
\end{tabular}

In vitro studies of phage pharmacokinetics using mathematical models do not necessarily reflect the in vivo phage kinetics observed. For instance, phage T4 was reported to not replicate in vitro at host concentrations below $10^{4}$ per $\mathrm{mL}$, but evidence suggests that this is possible in murine models [27]. Phage feeding experiments in animals and humans frequently report irregular shedding and the passage of high percentages (up to $90 \%$ administered) of phages in feces [27]. The failure of many phage therapy experiments has been related to a poor understanding of phage pharmacokinetics, for instance, when dosing relies too much on the self-replicating nature of phages [20].

Phage lytic enzymes (endolysins) can also be used for therapy, but their kinetics are more similar to conventional treatments. For example, Jun et al. [28] determined that a Staphylococcus aureus specific endolysin had a half-life between 0.04 and $0.38 \mathrm{~h}$ after intravenous administration in healthy volunteers. The decay kinetics of this endolysin is likely explained by the presence of plasma proteases. Other endolysins have demonstrated a longer half-life such as $11.3 \mathrm{~h}$ for CF-301 and 5.2-5.6 h (for 30 and $60 \mathrm{mg} / \mathrm{kg}$, respectively) for P128 [29,30]. 
Toxin (e.g., endotoxin) release due to significant bacterial cell lysis could potentially trigger septic shock during phage therapy. However, antibiotics like amikacin, cefoxitin, and imipenem have been shown to induce higher amounts of released endotoxin than coliphages [31]. The increase in endotoxin produced after 180 min incubation of E. coli LM33 was 3.8-fold with phage LM33_P1, 5.5-fold with amikacin, 8.7-fold with cefoxitin, and 30-fold with imipenem. With E. coli strain 536, there was a 19.8-fold increase in endotoxin with amikacin, 29.9-fold with phage 536_P1, 53.7-fold with imipenem, and 125.1-fold with ceftriaxone [31].

So, whilst less of an issue than for most conventional antibiotics, high fragmentation of the cell wall must be minimized with either phage or phage endolysin therapies to prevent an increase in pro-inflammatory cytokines [19,32]. To address this potential issue, several groups have proposed genetically engineering phages to prevent or reduce cell lysis, whilst still causing cell death by mechanisms such as degrading the host genome (see Section 7 and [33]).

\section{Role of the Immune Response in Phage Therapy}

Phages can potentially trigger innate and adaptive immune cells that may influence the success of phage therapy. Three major fields of phage-immune interaction can be discerned. First, involving immune recognition via pattern recognition receptor (PRR), which is a means for the recruitment of phagocytes to the infection site [34]. Phages can mediate the activation of innate immune cells when PRR recognizes phage-derived DNA and RNA. The extent of immune activation will differ depending on the phage type, the phage dose, and in vivo nucleic acid synthetic activity.

Second, promoted phage-neutralizing antibodies can hamper therapeutic success and this effect can increase with repeated administration [35]. Antibody induction against phages is considered to be highly variable, thus immunogenicity should be considered during phage screening prior to phage therapy. There are several externally presenting proteins on phages such as Hoc, which can potentially induce such an immune response [36-38]. Strategies to avoid phage-induced neutralizing antibody formation include refining dose concentrations, the use of low-multi-dose regimes, or low-dose passive therapy approaches.

Third, the inhibitory effect of humoral (adaptive) immunity and anti-phage antibody production on phages in the mammalian system is broadly known. Effects seem dose-dependent, with only high doses for long periods inducing specific responses. For instance, Majewska [39] developed a long-term study of antibody induction (IgM, IgG, secretory IgA) in mice fed T4 phage orally at high doses $\left(10^{9} \mathrm{PFU} / \mathrm{mL}\right.$ drinking water). No effect was noted in the first two weeks, then in weeks $3-5$, there was an increase in blood serum IgG. IgM did not increase until IgG began increasing, while IgA did not increase until days 63-79, but when it reached its maximum, no phage was found in the mouse feces. Increased IgA concentrations antagonized the gut transit of active phage and phage resistant hosts dominated the gut flora by day 92. However, IgA was rapidly cleared after phage withdrawal [39]. A similar study determined the immunological response of Pseudomonas phage F8 and T4 treatment in a murine systemic inflammatory response syndrome (SIR) model. The primary (IgM) and the secondary (IgG) responses inhibited the phages, and phage concentration in the spleen was significantly decreased [40].

Human trials in 26 patients with immunodeficiency diseases were undertaken to evaluate immunologic responses to phage $\phi X 174$. An intravenous dose of $10^{9} \mathrm{PFU} / \mathrm{kg}$ body weight was given, and the phage titer measured in blood. No antibody response was detected in eight cases of infantile X-linked agammaglobulinemia with circulating phages present for up to 11 days. The other 18 patients produced antibodies and phages were cleared from circulation within four days. Ten of these patients showed the IgM antibody, and eight patients produced both IgM and IgG [41]. Other work using $\phi X 174$ [42] has demonstrated that repeated (up to quaternary) dosing of phages does not lead to serious adverse reactions.

It is currently not well understood if anti-phage antibodies could prevent bacterial resistance development to phages and if the pre-existing immunity to natural phages could affect phage therapy. Furthermore, there is no clear information about the impact of phage-specific factors on phage clearance 
mechanisms. There are also gaps in our understanding of the clinical relevance of the phage immune interaction. Nevertheless, the immunogenicity of phages itself does not seem to represent a significant safety risk for patients. Reports about immune effects in clinical studies using virulent phages are limited. The introduction of validated in vitro and in vivo methods to determine the comparability of immune effects of different phages and phage combinations would be indispensable. This would allow for valid conclusions on the value of immune-based parameters for the selection of phages, identification of responsive patient populations, exchangeability of phages, and the importance of individualized phage cocktails [33]. The engineering of phages to make them less immunogenic is also an area of active research (see Section 7).

\section{Resistance to Phages}

An important consideration for phage therapy is the potential for bacterial resistance. Phage-resistant bacteria have been noted in up to $80 \%$ of studies targeting the intestines and $50 \%$ of studies using sepsis models, with phage-resistant variants also observed in human studies [43].

As with resistance to classical antibiotics, spontaneous resistance to phages may occur through a number of mechanisms. For example, the cell surface target receptor(s) may not be expressed or become mutated, thus causing a complete loss of adsorption or decreased adsorption. This is a limitation of both phage and conventional antibiotic therapy. For both approaches, knowing the receptor site(s), their stability, and conservation across strains will help with the mitigation of resistance.

Acquired resistance is another area that requires investigation for both therapeutic approaches. Accessory genetic elements such as plasmids, temperate phages, and mobile genetic islands can carry genes coding for resistance to antibiotics. For phages, acquired resistance can encompass CRISPR-Cas systems [33], immunity proteins produced by temperate phages (though rare) and the acquisition of DNA restriction-modification systems.

A key advantage of phage therapy over conventional treatments for the avoidance of resistance development is the deployment of phage cocktails. The use of several phages, each targeting different receptors and each of a diverse genetic clade will enhance the ability to mitigate against the loss of adsorption or host genetic protection mechanisms. Genetic engineering may also provide a means to improve the diversity and targeting efficiency of phages for the avoidance of resistance (see Section 7). Another consideration is that bacterial mutations that confer phage-resistance often result in fitness costs to the resistant bacterium. Therefore, understanding and exploiting the fitness costs to resistant pathogens during therapy is a potentially promising research avenue [43].

\section{Phage Therapy Clinical Trials in Humans}

To date, human phage therapy trials have largely been empirical, with routine use limited to Georgia, Poland, and Russia [44]. In particular, the George Eliava Institute in Georgia has longstanding experience with the selection, isolation, and preparation of monophage and phage cocktails against a variety of bacterial pathogens for phage therapy. The therapeutic application of phages has also been undertaken for several decades at the Institute of Immunology and Experimental Therapy in Poland [45]. However, the experimental clinical data published in Russian and Polish journals are difficult to access due to security and language barriers.

Although the reporting and assessment of phage therapy need to improve, particularly with regard to efficacy and tolerability and the use of adequate patient numbers, several successful case reports have been published. The reports do provide some evidence that the development of phage therapy is a promising alternative to combat bacterial resistance to antibiotics.

In France, the national health regulator has authorized the first treatment of patients with extremely drug-resistant and difficult to treat infections using phage therapy. Since then, six cases with various bacterial infections have been successfully treated [44]. Even though several treatments were not conducted using clinical standards suitable for drug approval in the Western world, they showed therapeutic potential for phages and how phages can be applied [45]. 
New therapeutic products must usually go through a long and comprehensive process involving preclinical and clinical trials to gain regulatory approval for market access. In the US, the average time for the approval of a new drug from preclinical testing is 12 years and the costs run into millions of dollars due to the length, size, and complexity of human clinical trials. For these reasons, the number of formal phage therapy clinical trials (as listed on www.ClinicalTrials.gov or https://globalclinicaltrialdata.com/) is very limited [45]. However, some of the human phage therapy clinical trials underway are summarized in Figure 1 and are described in the following case studies.

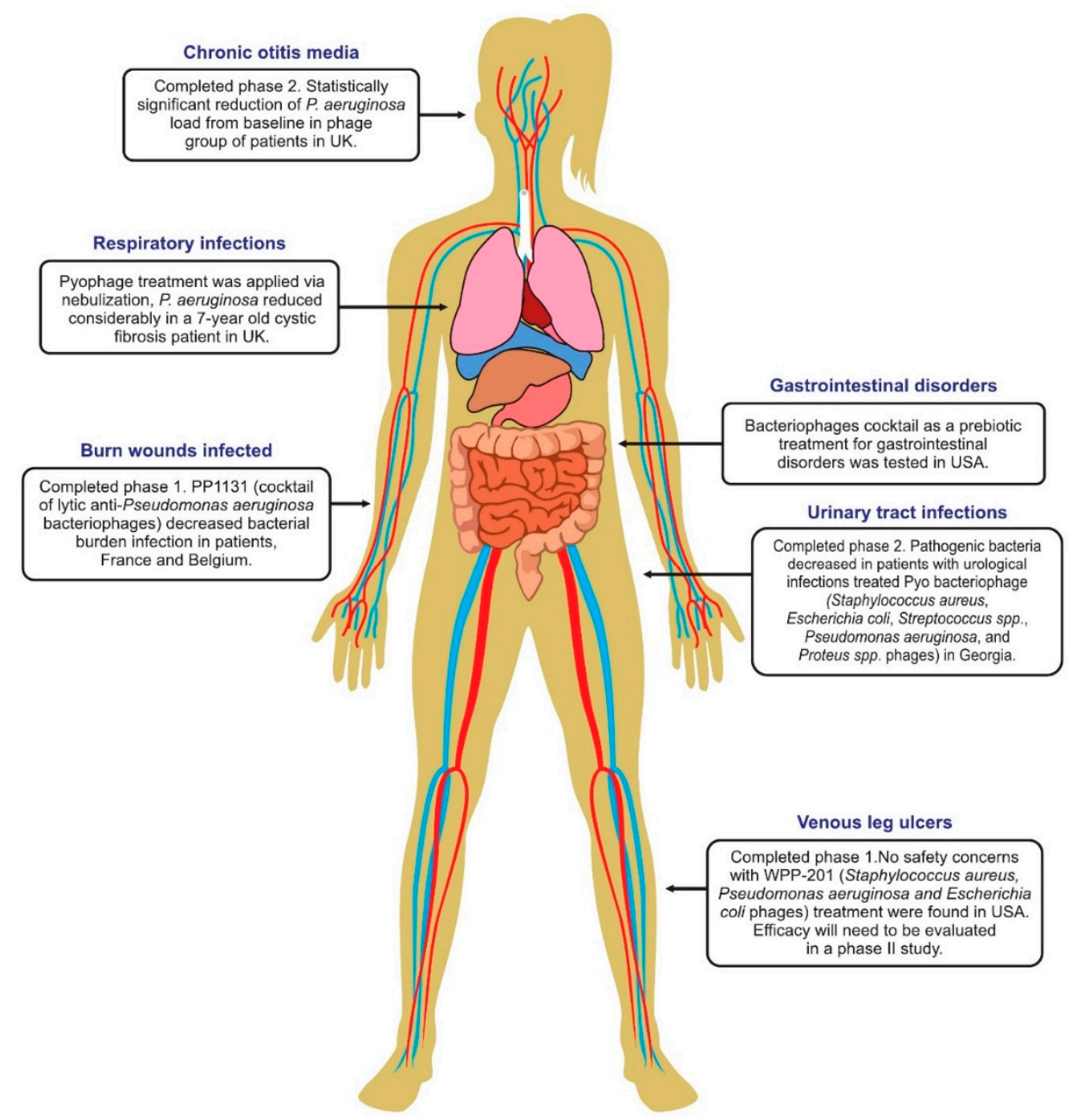

Figure 1. Human phage therapy trials and the range of target sites/infections. Image adapted from Furfaro et al. [46].

\subsection{Phage Treatment of Burns}

Phage therapy was applied in wound infections in 27 patients from hospitals in France and Belgium using a cocktail of virulent anti-Pseudomonas aeruginosa bacteriophages. Participants were randomly assigned (1:1) to a cocktail of 12 natural virulent anti-P. aeruginosa bacteriophages $\left(10^{6}\right.$ plaque-forming units [PFU] per $\mathrm{mL}$ ) or standard of care (1\% sulfadiazine silver emulsion cream), and the route of administration was topical for seven days, with 14 days of follow-up [44].

The median of the primary endpoint was $144 \mathrm{~h}$ in the phage treatment group and $47 \mathrm{~h}$ in the standard of care group. Three (23\%) of the 13 analyzable participants showed adverse events in the phage treatment group when compared with seven (54\%) out of 13 in the standard care group. Bacteria isolated from patients of the failed phage treatment were resistant to low phage doses [44]. 
This study showed that phage treatment decreased bacterial burden in burn wounds in more time than the standard treatment. In this regard, studies increasing the phage concentration and the use of "phagograms" (as used for antibiograms) with more patients are warranted.

\subsection{Treatment of A Septicemia Patient with Acute Kidney Damage}

A man in his sixties was hospitalized for Enterobacter cloacae peritonitis and severe abdominal sepsis, dispersed intravascular coagulation, herniation, and bowel strangulation. Following prolonged treatment for these ailments, the patient developed gangrene and pressure sores colonized by drug-resistant $P$. aeruginosa. The infection developed to septicemia and colistin treatment (the only drug sensitivity) was carried out, however, acute kidney damage was detected, and the treatment was suspended. Subsequently, phage therapy against $P$. aeruginosa was conducted using a mixture of two phages active against the isolate in vitro, under the umbrella of Article 37 (Unproven Interventions in Clinical Practice) of the Declaration of Helsinki [46]. Following phage therapy, the patient showed improved kidney function, which returned to normal function after a few days, and blood cultures were negative.

However, the patient's pressure sores remained infected with P. aeruginosa and other species and four months later, the patient developed a refractory cardiac arrest due to blood culture-confirmed Klebsiella pneumoniae sepsis and the patient died. In vivo studies revealed that a K. pneumoniae strain isolated from the patient was sensitive to the antibiotics. According to historical reports, the use of phages by intravenous route in typhoid fever and Staphylococcus aureus [47] bacteremia were efficacious, nevertheless, this is the first contemporary report using phage monotherapy against $P$. aeruginosa septicemia in humans through the intravenous route [48].

\subsection{Engineered Phages for Treatment of Mycobacteria in A Cystic Fibrosis Patient}

Therapeutic phage treatment for mycobacteria has been explored in several animal models [49,50], but until recently had not been successfully used for mycobacterial infections in humans. A 15-year-old patient with cystic fibrosis and extensive comorbidities was referred for lung transplant with a disseminated infection of Mycobacterium abscessus. Following bilateral lung transplantation and persistent $M$. abscessus infections, phage genome engineering and forward genetics were used to engineer phages to target and kill the infectious $M$. abscessus strain. Therapy was conducted using an intravenous three-phage cocktail of $10^{9} \mathrm{PFU}$ of each phage every $12 \mathrm{~h}$ for 32 weeks [51].

Intravenous phage treatment was well tolerated, clinical improvement including sternal wound closure, improved liver and lung function, and substantial resolution of infected skin nodules were detected in the six months following therapy. No evidence of phage neutralization was detected in sera, although weak antibody responses to phage proteins were identified. Weak cytokine responses were reported for interferon- $\gamma$, interleukin-6, interleukin-10, and tumor necrosis factor- $\alpha$ [51]. Some evidence was presented that indicated active in vivo phage replication was taking place. Despite the apparent success of this therapy, the authors did caution that there was significant variation in M. abscessus phage susceptibility, so the treatment of similar patients will require more work to be undertaken to understand the science underlying this observation.

\subsection{Phage Therapy for Respiratory Infections}

There have been several pre-clinical studies describing the use of phage therapy against chronic bacterial lung infections using murine models. Pabary et. al. [52] determined that phage treatment reduced the infective burden and inflammatory response in the murine lung. All phage-treated mice cleared $P$. aeruginosa infection at $24 \mathrm{~h}$, whereas infection persisted in all of the control mice. Phage also reduced infection and inflammation in bronchoalveolar lavage fluid when administered prophylactically. Another study showed that intranasal treatment with phage rescued mice from Acinetobacter baumannii-mediated pneumonia. Microcomputed tomography also indicated a reduction in lung inflammation in mice given phage [53]. In a study using a biofilm-associated murine model 
of chronic lung infection, phage therapy was effective seven days post-infection. Additionally, these studies established the potential for phage therapy in established and recalcitrant chronic respiratory tract infections [54].

Notwithstanding the reported treatment of Mycobacterium described in Section 6.3, reports of phage therapy of human bacterial respiratory infections are rare. In a 2011 case study from Georgia, a seven-year-old cystic fibrosis (CF) patient presented with chronic colonization of P. aeruginosa and S. aureus with antibiotic treatments having limited effect. Phage therapy was undertaken using a "Pyo phage" phage cocktail produced by the Eliava Institute, which reportedly contains phages active against $S$. aureus, Streptococcus, Proteus, P. aeruginosa, and E. coli [55]. The Pyo phage cocktail was delivered to the patient via nebulization at four-to-six week intervals for nine rounds of treatment. The $P$. aeruginosa numbers reduced considerably, however, the treatment was not effective against S. aureus. Consequently, Sb-1 phage (a phage targeting S. aureus) was added to the Pyo phage cocktail and administered five times with a nebulizer. This treatment reduced the concentration of S. aureus significantly. No adverse effects were detected in the patient upon Sb-1 phage treatment [55].

Recent advances in the spray drying of phages that have achieve increased numbers of phages delivered to the lungs (up to $10^{8} \mathrm{PFU} /$ aspiration) may considerably improve clinical outcomes for respiratory infections such as these [56]. Work has also shown that a cocktail of ten phages significantly decreased P. aeruginosa numbers in sputum samples from $58 \mathrm{CF}$ patients collected from hospitals in Paris [45,57]. Forty-eight of 58 samples were positive for P. aeruginosa and the addition of phages significantly decreased the concentrations of $P$. aeruginosa in the sputum. An increase in the number of bacteriophages in $45.8 \%$ of these samples was also detected, demonstrating the potential for active phage therapy of respiratory infections in vivo.

\subsection{Phage Therapy for Urinary Tract Infections}

Therapy for treating urinary tract infections (UTIs) is one of the most promising applications for phages and one of the few that have been studied in a multi-stage clinical trial. In the first stage of the trial, 130 patients planned for transurethral resection of the prostate were screened for UTIs and 118 patients enrolled [58]. Criteria for inclusion in the trial were having $\geq 10^{4} \mathrm{cfu} / \mathrm{mL}$ of the pathogens S. aureus, E. coli, Streptococcus, P. aeruginosa, or Proteus mirabilis in their urine culture. Initial in vitro screening of these cultures against the Pyo phage cocktail, a commercial product produced by the Eliava Institute, revealed that the sensitivity was $41 \%$ (48/118). Directed evolution experiments were applied to the cocktail to select for expanded host range phages, and the sensitivity was improved to $75 \%(88 / 118)$.

In the second stage, nine patients who had infections caused by bacteria sensitive to the Pyo cocktail underwent non-blinded phage therapy. Administration of $20 \mathrm{~mL} 10^{7}-10^{9} \mathrm{PFU} / \mathrm{mL}$ phages was via a suprapubic catheter twice every $24 \mathrm{~h}$ for seven days, starting the first day after surgery. Urine from the patients was subsequently cultured seven days after surgery or at the time of adverse indications. Prior to therapy, the patients' urine screening revealed the presence of $E$. coli in four cases, Enterococcus in two cases, Streptococcus in two cases, and P. aeruginosa in one case. Following therapy, titers of the pathogens decreased by $1-5 \log \mathrm{cfu} / \mathrm{mL}$ in six out of nine patients. One of the four E. coli cases had no detectable pathogen, one of two Streptococcus cases had no detectable pathogen, one of the Enterococcus cases had no pathogens, but the other case detected E. coli. The patient with the $P$. aeruginosa infection required antibiotic therapy following a spike in fever and became asymptomatic; however, P. aeruginosa was detected in his urine. No adverse effects of phage therapy were detected. The study authors hope to further progress this work to full randomized and blinded control studies in the future.

\subsection{Phage Therapy for Diarrhea}

Whilst no longer an active partnership, the Nestlé Research Centre in Switzerland and the International Centre for Diarrhoeal Diseases Research in Bangladesh have undertaken joint research 
projects over a number of years that have explored the efficacy of phage therapy for the treatment of diarrheal diseases. In one of the studies, 120 Bangladeshi male children (6-24 months) presenting with acute bacterial diarrhea were given either $3.6 \times 10^{8} \mathrm{PFU}$ of a T4-like coliphage cocktail (39 children), $1.4 \times 10^{9} \mathrm{PFU}$ of a commercial coliphage preparation (Coliproteus from Microgen, 40 children), or a placebo $(0.9 \% \mathrm{NaCl}, 41$ children) suspended in oral rehydration solution.

Results of this randomized blind trial indicated no adverse effects of oral phage treatment of the children. The phage survived the gastric passage, but there was no strong evidence of intestinal replication occurring in patients. Neither the T4-like nor the Microgen coliphage cocktail showed a significant clinical effect when compared to the control group for stool output or frequency, or rehydration. Likely reasons for the lack of significant effects were the lower than expected incidence of E. coli $(60 \%)$ and the incidence of mixed species infections, the presence of non-susceptible coliforms (phage cocktail was not optimized for local isolates), and insufficient phage titer [59,60].

\subsection{Treatment of Peri-Prosthetic Joint Infection}

In this case study [61], an 80-year-old female patient with obesity and a history of relapsing prosthetic joint infection of the right hip presented with a S. aureus postoperative infection and was treated with debridement, antibiotics, and implant retention (DAIR). Four years later, another DAIR was performed for fluoroquinolone-resistant E. coli, following reimplantation surgery in the prior year. Then, due to a relapse including positive E. coli cultures, another DAIR was performed three weeks later. Antibacterial therapy with ceftriaxone was started; however, there were further signs of relapse and antibiotic treatment was stopped. Multidrug-resistant $P$. aeruginosa and penicillin-resistant S. aureus were identified in swabs of the wound discharge.

To undertake phage therapy, three phages targeted against the P. aeruginosa isolate were first prepared by Pherecydes Pharma (France). The S. aureus isolate was lost, so three phages from the Pherecydes Pharma phage bank were used. Phages were produced in a research environment with the manufacture overseen by The French National Agency for Medicines and Health Products Safety (ANSM). The final formulation of the P. aeruginosa and S. aureus phages were undertaken by the hospital pharmacy by mixing equal volumes of $10^{10} \mathrm{PFU} / \mathrm{mL}$ phage stocks. During the following DAIR, $20 \mathrm{~mL}$ of the phage cocktail was injected into the joint region. Co-therapy with antibiotics (daptomycin, amoxicillin, and clindamycin) was followed for the next six months without signs of P. aeruginosa or S. aureus infection. The patient later had a Citrobacter infection, which required DAIR, but once this was treated with Ciprofloxacin, no further infection was found in the joint (18 months post-phage therapy).

The bespoke use of phage and antibiotic combinations to treat a patient's infection has the potential to be utilized to create personalized therapy for deep and persistent tissue infections such as those found associated with peri-prosthetic joints (Figure 2). 


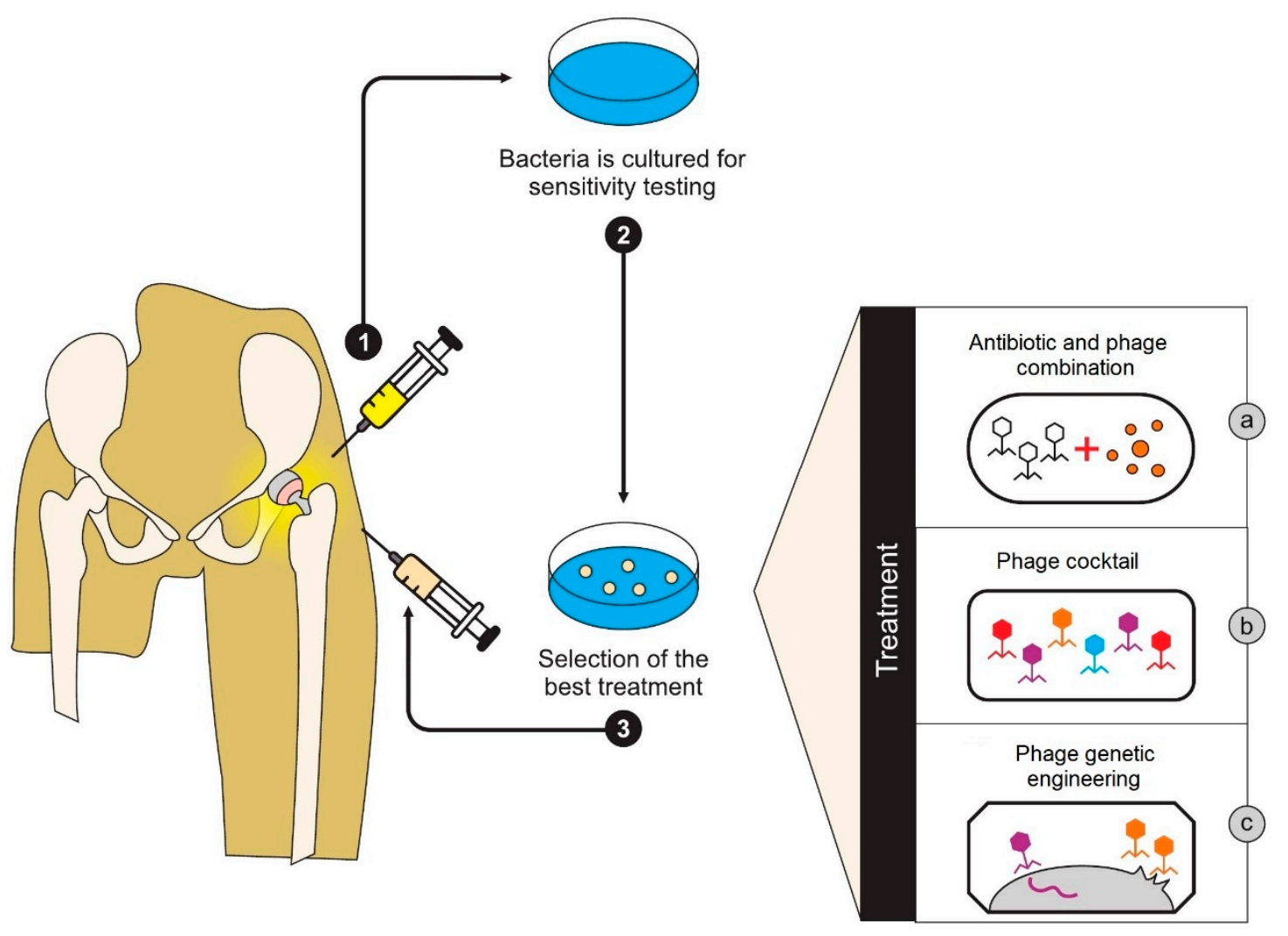

Figure 2. Personalized combinatorial phage therapy. Image adapted from Akanda et al. [62].

\subsection{Treatment of Leg Ulcers}

A Phase I trial of phage therapy with 42 patients with chronic venous leg ulcers has been undertaken [63]. Ulcers were treated for 12 weeks with a phage cocktail (WPP-201; $8 \times 10^{7} \mathrm{PFU} / \mathrm{mL}$ ) or a control (saline). The phage cocktail targeted P. aeruginosa, S. aureus, and E. coli. Patient follow-up continued until week 24 and no adverse events were attributed to the phage treatment. There was no significant difference between the phage therapy group and the control group for the rate or frequency of ulcer healing. Efficacy of the preparation will need to be evaluated in a phase II efficacy study.

\subsection{Therapy of Drug-Resistant Craniectomy Infection}

A previously healthy 77-year-old male who suffered assault, subdural hematoma, and traumatic brain injury underwent a craniectomy, which was complicated by postoperative intracranial infection with multidrug-resistant $A$. baumannii. The isolate was resistant to all antibiotics; however, some isolates were sensitive to colistin [64]. An emergency investigational new drug application to use phage therapy on the patient was approved by the US Food and Drug Administration. Phages from the Naval Medical Research Center-Frederick were screened against the isolate and the most active phage prepared.

The phage $\left(2.1 \times 10^{7} \mathrm{PFU} / \mathrm{mL}\right)$ was administered intravenously through a central catheter line every $2 \mathrm{~h}$ for eight days, with 98 total doses given. Following phage treatment, the patient initially seemed more alert, but continued to be unresponsive. The craniotomy site and skin flap healed well, though fevers and leukocytosis continued. There were no further signs of infection at the craniotomy site after surgical debridement. However, bacterial cultures obtained prior to phage administration were negative, therefore it was not possible to directly measure phage efficacy. Before the receipt of a second phage cocktail, the patient's family decided to withdraw care and the patient died.

The authors concluded that administration of phages through the surgical drain would likely have had more benefit than parenteral administration, less targeted phages with broader activity may 
have been more efficacious, and a better outcome might have been possible if personalized phage therapy had been developed more quickly and administered earlier in the course of infection.

\subsection{Therapy of Ear Infections}

A Phase I/II research trial was conducted in the UK to test the efficacy and safety of phages for the treatment of chronic ear infections (otitis media), where the infection is known to harbor antibiotic-resistant $P$. aeruginosa [65]. In this randomized double-blinded study, a cocktail of six phages produced by Biocontrol Limited (BiophagePA, $6 \times 10^{5} \mathrm{PFU}$ ), or placebo (glycerol-PBS solution) were administered to the ear canal of 24 patients. The follow-up to treatment was at 7, 21, and 43 days and revealed a statistically significant improvement in both clinical condition and patient-reported indicators for the phage treated group when compared to the control. No adverse reactions were noted in the phage-treated group.

In vivo replication of phages in the patients was evident for up to 23 days, with the mean recovery of phages during the trial sampling points being 200 times the input concentration. Clearance of phages was noted when the P. aeruginosa infection was resolved in patients. Reductions in overall $P$. aeruginosa numbers in the phage treatment group, whilst statistically significant, were generally modest, but measurement was likely to be compromised by the lack of access to deep parts of the ear canal. When P. aeruginosa was not completely cleared by phage therapy, there was an increase in clinical scores for some patients. The study authors suggest that repeated phage therapy after three to four weeks may be beneficial to these types of patients in any future work.

\section{Engineering and Other Genetic Technologies for Phage Therapy}

The advent of whole-genome sequencing and metagenomics have rapidly increased the number of phage genomes sequenced and is unlocking new insights into phage genetics. The use of this new knowledge for phage engineering holds great potential to increase the utility of phages for therapy, however, there are additional considerations such as ethical, safety, and regulatory, which need to be accounted for above that of 'natural' phage therapy. Engineering can be used to produce new variants of phages with expanded host range, decreasing the number of phage strains needed to cover bacterial diversity, and generating patentable phage variants [66-68]. For example, the host specificity of the E. coli K12-specific phage T2 was able to be changed by swapping gene products expressed at the tip of the long tail fiber with those of the PP01 phage, which is an E. coli O157: H7-specific phage [66]. The recombinant phage was able to infect E. coli O157: $\mathrm{H} 7$ and related strains, but could not infect E. coli $\mathrm{K} 12$ or its derivatives. Similarly, homologous recombination was used to replace the long tail fiber genes (genes 37 and 38) from the genome of T2 with those of the IP008 phage. The recombinant T2 phage had a host range identical to that of IP008 [67]. Lin et. al. [68] were also able to modify the E. coli female-specific T7 phage to overcome male exclusion by recombination with phage T3. The recombinant phages of T3 and T7 carried altered tail fibers and had better adsorption efficiency than T3.

Genetic engineering of phage permits the addition of novel functionality such as bacteriocins, enzybiotics, quorum sensing inhibitors, CRISPRs, and biofilm degrading enzymes that can enhance their killing potential [69-73]. Phages can be modified using the RNA-guided nuclease Cas9 to create sequence-specific antimicrobials. Cas9 was reprogrammed to target virulence genes and killed virulent, but not avirulent, strains of $S$. aureus in a mouse skin colonization model [65]. Another study used CRISPR-Cas technology to create RNA-guided nucleases delivered by phages to target specific DNA sequences in carbapenem-resistant Enterobacteriaceae and enterohemorrhagic E. coli [70]. Delivery of the nucleases improved the survival in a Galleria mellonella infection model. Phage-borne CRISPR-Cas systems can also be used to enable site-specific cleavage to induce cytotoxicity, activate toxin-antitoxin systems, re-sensitize bacterial populations to antibiotics, and modulate bacterial consortia [70].

Biofilms are the major cause of persistent infections in clinical settings, thus phage treatment to lyse bacteria in biofilms has attracted growing interest. An engineered T7 phage was constructed to 
encode a lactonase enzyme with broad-range activity for the quenching of quorum sensing molecules necessary for biofilm formation. The T7 phage incorporating the AHL lactonase aiiA gene from Bacillus anthracis degraded AHLs from diverse bacteria and caused the inhibition of a mixed-species biofilm composed of P. aeruginosa and E. coli [71]. In another approach using the T7 phage, a biofilm-degrading enzyme, DspB, produced by Actinobacillus actinomycetemcomitans, was inserted into the T7 genome and the resultant phage reduced $E$. coli biofilm cell counts by an additional 2 log when compared to the unmodified T7 [72].

As described in Section 4, components of the innate immune system can remove a significant proportion of administered phage. Studies have shown that long-circulating phage mutants can be isolated to address this issue. Vitiello et. al. [73] determined that a single specific substitution in the major phage capsid (E) protein of the lambda Argo phage was enough to confer a long-circulating phenotype that enhanced phage survival in the mouse circulatory system by more than a 1000-fold. Merril et. al. [74] used a serial passage selection method to isolate phage mutants with a greater capacity to remain in the circulatory system of the mouse. Lambda phage mutants with 13,000-16,000-fold better capacity to stay in the mouse circulatory system for $24 \mathrm{~h}$ after intraperitoneal injection were isolated.

Many antibiotics, as well as phage therapy, can present side effects due to endotoxin release from Gram-negative bacteria. To address this, genetic engineering was used to generate non-replicating non-lytic phage targeting P. aeruginosa. An export protein gene of the P. aeruginosa filamentous phage Pf3 was replaced with a restriction endonuclease gene and the variant (Pf3R) was non-replicative and prevented the release of phage from the target cell. Endotoxin release was kept to a minimum and the Pf3R phage efficiently killed a wild-type host in vitro. Phage therapy using Pf3R showed comparable or increased survival rates (depending on dose) when compared to Pf3 upon challenge in the mice model. Higher survival rates were correlated with a reduced inflammatory response when using Pf3R treatment [75]. Matsuda et. al. [76] also produced lysis-deficient T4 phages for this purpose. Mutant $t$ amber A3 T4 phages were compared to wild-type T4 in mouse bacterial peritonitis model. Survival was significantly higher in mice treated with the lysis deficient phage when compared to the wild-type, and enterotoxin levels were significantly lower in the t A3 T4-treated mice at 12 hours after infection [76].

\section{The Medicinal Regulatory Status of Phages}

Phages are not specifically classified as living or chemical agents in any national medicinal legislation (as far as we are aware). This considerably complicates the regulation of human phage therapy clinical trials and commercialization of phage products as well-established safety, good manufacturing practice, and efficacy benchmarks are lacking [77]. Another barrier is that in order to prove the efficiency of phage preparations, their effectiveness and host range toward currently circulating pathogenic strains must be constantly monitored. This is most likely why the Russian Federation and Georgia approved phage preparations are continuously updated to target newly emerging pathogenic strains [78]. Therefore, any specific legislation regarding phage products would ideally permit these formulation updates as required to avoid repeated registration procedures.

A breakthrough for the regulation of phage therapy occurred in 2016, when the Belgian Minister of Social Affairs and Public Health defined the status of therapeutic phage preparations as industrially-prepared medicinal products (subjected to constraints related to marketing authorization) or as magistral (compounded) preparations prepared in the pharmacies' officinal [79]. Natural phages and their products can be processed by a pharmacist as raw materials (active ingredients) in magistral preparations, providing there is compliance with several provisions of the European Directive requirements for medicinal products for human use [78].

Several jurisdictions also permit the use of phages on compassionate grounds, where all other therapies have failed, and the condition is immediately life-threatening. These include the US FDA Expanded Access Program (www.fda.gov/news-events/public-health-focus/expanded-access) and Investigational Drug Program (https://www.fda.gov/drugs/types-applications/investigational-new- 
drug-ind-application) and the European Medicines Agency (https://www.ema.europa.eu/en/humanregulatory/research-development/compassionate-use).

\section{Advantages and Disadvantages of Phage Therapy}

Compared to conventional antibiotic therapy for bacterial infections, phage therapy has both a number of great advantages, but also some disadvantages. Some of these have been summarized in Table 2 and some aspects are discussed in more detail in the following subsections.

Table 2. Advantages and disadvantages of phage vs. antibiotic therapy for the treatment of bacterial infections.

\begin{tabular}{|c|c|c|}
\hline Consideration & Antibiotic Therapy & Phage Therapy \\
\hline Specificity & Low & High \\
\hline Development costs & High & Low-moderate \\
\hline Side effects & Moderate-high & Usually low, but yet to be fully established \\
\hline Resistance & $\begin{array}{l}\text { Increasing incidence of multi-drug } \\
\text { resistant isolates. }\end{array}$ & $\begin{array}{l}\text { Can treat multi-drug-resistant isolates. Phage } \\
\text { resistant isolates generally lack fitness. }\end{array}$ \\
\hline Delivery to target & Moderate & $\begin{array}{l}\text { Moderate to good. Can penetrate the blood-brain } \\
\text { barrier. }\end{array}$ \\
\hline Formulation & Fixed & Fixed or variable \\
\hline Regulation & Well established & Underdeveloped \\
\hline Kinetics & Single hit & Single hit or self-amplifying \\
\hline Immunogenicity & Variable & Likely low, but not well established \\
\hline Clinical validation & Many trial studies & Relatively few trial studies \\
\hline
\end{tabular}

\subsection{Key Advantages}

Phage therapy has several key advantages that make it an attractive alternative to antibiotics. First, phages have high specificity to their hosts and unlike antibiotics, which have a much wider spectrum, are unlikely to cause dysbiosis and secondary infections (e.g., fungal infections). To date, phages have also not shown any significant side effects or risks of toxicity on mammalian cells [80]. Moreover, the process of isolation and selection of new phages is less expensive, in terms of time and costs, than the development process required for antibiotics: it typically takes millions of dollars and numerous years to develop an effective antibiotic drug [81].

The development of the resistance of bacteria to phage therapy is likely less significant than for antibiotics because of the ability to adapt phage cocktails by the substitution of phages, applying in vitro evolutionary pressure, or by genetic engineering. The variant resistant mutants are also generally of lower fitness. Phages are also able to successfully treat multi-drug-resistant bacteria as they use different mechanisms for targeting cells.

The ability of phages to widely spread through the body when applied by systemic administration, along with self-replication in the presence of the host, are qualities that most antibiotics do not have. Unlike most antibiotics, phages can also pass through the blood-brain barrier [82]. Some phages can also infiltrate and disrupt the biofilms that many pathogens naturally inhabit [82,83].

For patients with allergies to antibiotics, their treatment options can be restricted. About $1 \%$ of hospitalized patients have an allergy to penicillin-group drugs, the most common antibiotic allergy, followed by sulfonamides and tetracyclines [84]. Cross-reaction of penicillin allergies to next-generation cephalosporins and carbapenems has also been reported, but this remains controversial [85]. Phage therapy may be a valuable option for patients with antibiotic allergies, but reports are rare. For example, 12 patients with inflammatory soft tissue shotgun wounds and allergy to antibiotics (not specified) were reported to have been treated by polyvalent phage therapy (Staphylococcus, Streptococcus, Proteus 
vulgaris, Proteus mirabilis, P. aeruginosa, E. coli, and K. pneumoniae) for 15 days [86]. The concentrations of bacteria and the areas of wound healing were similar in the phage treatment group when compared to a control group of 35 patients receiving antibiotics. The authors concluded that phages were a reliable method for reducing microbial infection and that treatment led to a rapid epithelialization of the wound site [86].

\subsection{Key Disadvantages}

There are currently some key disadvantages of using phages as alternatives for antibiotics. However, these are predominantly due to gaps in knowledge and regulations, which may be resolved in the future. Critically, there is a lack of depth of information about the clinical application of phages for controlling bacterial infections. Much experimental clinical data published in Russian and Polish journals are difficult to access due to security and language barriers. There are also many more challenges for scientists in obtaining regulatory approval for phage-based therapeutic applications when compared to conventional therapies [80].

There is a lack of common established and validated protocols for the routes of administration, dose, frequency, and duration of phage treatment, which hampers inter-study comparison [87]. Often, the purity and stability of phage preparations used for clinical trials are also uncertain, with insufficient quality control data presented.

The concentration of phages may be reduced significantly during therapy by the reticuloendothelial system or be neutralized by antibodies, thus inhibiting their antimicrobial activity [39,88]. However, the effect of phage-neutralizing antibodies can be mitigated by refining dosing regimens and breeding phages to evade the immune system.

The genetic biosafety of phages is complex to assess. Phages used for therapy must not contain toxin or virulence genes, antibiotic resistance genes, or be able to horizontally transfer genes in the human microflora. Whilst whole-genome sequencing is a powerful tool to assist with these analyses, there is still an incomplete understanding of the functions of all encoded phage genes. Genetic engineering of phages will also likely invite greater scrutiny of safety which practitioners will need to address before application.

\section{Conclusions}

Antimicrobial resistance is increasing globally, and new treatments are urgently needed to meet this challenge in medical care. Whilst phage therapy for bacterial infections has been around for more than a century, the antibiotic-resistance crisis is providing renewed impetus for phage therapy to deliver on its long-held promise as a clinical treatment. As described here, there is an increasing number of well-executed Phase I/II clinical trials describing the safety and efficacy of phage therapy. There is an improved understanding of the pharmacology, immunology, safety, and potential for bacterial resistance. Technologies such as genetic engineering, whole-genome sequencing, and metagenomics also provide new tools to optimize phage therapeutic strategies. However, there are still data gaps on its efficacy and a lack of standardization and suitable regulatory frameworks that need to be resolved before phage therapy can take its place in mainstream medicine. Given the renewed interest and impetus in the field of phage therapy, there are reasons to be optimistic that these challenges can be met in the coming years.

Author Contributions: Conceptualization, D.R.-C. and C.B.; methodology, D.R.-C.; writing-original draft preparation, D.R.-C. and C.B.; writing-review and editing, D.R.-C., R.G.-B., A.G.-N. and C.B.; visualization, D.R.-C.; supervision, R.G.-B., A.G.-N. and C.B.; project administration, C.B.; funding acquisition, C.B.

Funding: This research was funded by an ESR Strategic Science Investment Fund grant to CB.

Conflicts of Interest: The authors declare no conflict of interest. The funders had no role in the design of the study; in the collection, analyses, or interpretation of data; in the writing of the manuscript, or in the decision to publish the results. 


\section{References}

1. Hendrix, R.W.; Smith, M.C.M.; Burns, R.N.; Ford, M.E.; Hatfull, G.F. Evolutionary relationships among diverse bacteriophages and prophages: All the world's a phage. Proc. Natl. Acad. Sci. USA 1999, 96, 2192-2197. [CrossRef] [PubMed]

2. Hendrix, R.W. Bacteriophages: Evolution of the Majority. Theoretical Population Biology. Popul. Biol. 2002, 61, 471-480. [CrossRef]

3. Abedon, S.T.; Kuhl, S.J.; Blasdel, B.G.; Kutter, E.M. Phage treatment of human infections. Bacteriophage 2011, 1, 66-85. [CrossRef] [PubMed]

4. Międzybrodzki, R.; Borysowski, J.; Weber-Dabrowska, B.; Fortuna, W.; Letkiewicz, S.; Szufnarowski, K.; Pawełczyk, Z.; Rogóż, P.; Kłak, M.; Wojtasik, E.; et al. Clinical aspects of phage therapy. Adv. Virus Res. 2012, 83, 73-121. [PubMed]

5. $\quad$ Reyes, A.; Semenkovich, N.P.; Whiteson, K.; Rohwer, F.; Gordon, J.I. Going viral: Next-generation sequencing applied to phage populations in the human gut. Nat. Rev. Microbiol. 2012, 10, 607-617. [CrossRef] [PubMed]

6. Weber-Dabrowska, B.; Jónczyk-Matysiak, E.; Zaczek, M.; Łobocka, M.; Łusiak-Szelachowska, M.; Górski, A. Bacteriophage Procurement for Therapeutic Purposes. Front. Microbiol. 2016, 7, 1177. [CrossRef] [PubMed]

7. Aminov, R.; Caplin, J.; Chanishvili, N.; Coffey, A.; Cooper, I.; De Vos, D.; Doškar, J.; Friman, V.; Kurtböke, I.; Pantucek, R.; et al. Application of bacteriophages. Microbiol. Aust. 2018, 38, 63-66.

8. NIH NIAID's Antibacterial Resistance Program: Current Status and Future Directions. 2014. Available online: http://www.niaid.nih.gov/topics/antimicrobialresistane/documents/arstrategicplan2014.pdf (accessed on 23 September 2015).

9. Moellering, R.C. NDM-1-A cause for worldwide concern. N. Eng. J. Med. 2010, 363, 2377-2379. [CrossRef] [PubMed]

10. Ceyssens, P.-J.; Lavigne, R. Introduction to Bacteriophages Biology and Diversity. In Bacteriophages in Control of Food and Waterborne Pathogens; Sabour, P.M., Griffiths, M.W., Eds.; American Society of Microbiology: Washington, DC, USA, 2010.

11. Guttman, B.; Raya, R.; Kutter, E. Basic Phage Biology. In Bacteriophages: Biology and Applications; Kutter, E., Sulakvelidze, A., Eds.; CRC Press Florida: Boca Raton, FL, USA, 2011; pp. 29-66.

12. Engelkirk, G.; Duben-Engelkirk, P. Burton's Microbiology for the Health Sciences, 9th ed.; Lippincott Williams and Wilkins: Philadelphia, PA, USA, 2011.

13. Drulis-Kawa, Z.; Majkowska-Skrobek, G.; Maciejewska, B.; Delattre, A.S.; Lavigne, R. Learning from bacteriophages-Advantages and limitations of phage and phage-encoded protein applications. Curr. Protein Pept. Sci. 2012, 13, 699-722. [CrossRef] [PubMed]

14. Abubakar, S.; Hauwa-Suleiman, B.; Ali Abbagana, B.; Alhaji-Mustafa, I.; Abbas-Musa, I. Novel Uses of Bacteriophages in the Treatment of Human Infections and Antibiotic Resistance. Am. J. Biosci. 2016, 4, 34-40. [CrossRef]

15. Available online: https://en.wikipedia.org/wiki/Listeria_phage_P100 (accessed on 1 August 2019).

16. Friman, V.P.; Soanes-Brown, D.; Sierocinski, P.; Molin, S.; Johansen, H.K.; Merabishvili, M.; Pirnay, J.P.; De Vos, D.; Buckling, A. Pre-adapting parasitic phages to a pathogen leads to increased pathogen clearance and lowered resistance evolution with Pseudomonas aeruginosa cystic fibrosis bacterial isolates. J. Evol. Biol. 2016, 29, 188-198. [CrossRef] [PubMed]

17. Love, M.; Bhandari, D.; Dobson, R.; Billington, C. Potential for Bacteriophage Endolysins to Supplement or Replace Antibiotics in Food Production and Clinical Care. Antibiotics 2018, 7, 17. [CrossRef] [PubMed]

18. Rafii, F.; Sutherland, J.B.; Cerniglia, C.E. Effects of treatment with antimicrobial agents on the human colonic microflora. Clin. Risk Manag. 2008, 4, 1343. [CrossRef] [PubMed]

19. Abdelkader, K.; Gerstmans, H.; Saafan, H.; Dishisha, T.; Briers, Y. The Preclinical and Clinical Progress of Bacteriophages and Their Lytic Enzymes: The Parts are Easier than the Whole. Viruses 2019, 24, 11.

20. Abedon, S.T.; Thomas-Abedon, C. Phage therapy Pharmacology. Cur. Pharm. Biotechnol. 2010, 11, $28-47$. [CrossRef]

21. Payne, R.J.H.; Phil, D.; Jansen, V.A. Phage therapy: The peculiar Kinetics of self-replicating pharmaceuticals. Clin. Pharm. Ther. 2000, 68, 225-230. [CrossRef]

22. Loc-Carrillo, C.; Abedon, S.T. Pros and Cons of phage therapy. Bacteriophage 2011, 2, 111-114. [CrossRef] [PubMed] 
23. Bull, J.J.; Regoes, R.R. Pharmacodynamics of non-replicating viruses, bacteriocins and lysins. Proc. Biol. Sci. 2006, 273, 2703-2712. [CrossRef] [PubMed]

24. McVay, C.S.; Velasquez, M.; Fralick, J.A. Phage therapy of Pseudomonas aeruginosa infection in a mouse burn wound model. Antimicrob. Agents Chemother. 2007, 51, 1934-1938. [CrossRef]

25. Tanji, Y.; Shimada, T.; Fukudomi, H.; Miyanaga, K.; Nakai, Y.; Unno, H. Therapeutic use of phage cocktail for controlling Escherichia coli O157:H7 in gastrointestinal tract of mice. J. Biosci. Bioeng. 2005, 100, 280-287. [CrossRef]

26. Semler, D.D.; Goudie, A.D.; Finlay, W.H.; Dennis, J.J. Aerosol phage therapy efficacy in Burkholderia cepacia complex respiratory infections. Antimicrob. Agents Chemother. 2014, 58, 4005-4013. [CrossRef]

27. Brüssow, H. Phage therapy: The Escherichia coli experience. Microbiology 2005, 151, 2133-2140. [CrossRef] [PubMed]

28. Jun, S.Y.; Jang, I.J.; Yoon, S.; Jang, K.; Yu, K.-S.; Cho, J.Y.; Seong, M.-W.; Jung, G.M.; Yoon, S.J.; Kang, S.H. Pharmacokinetics and tolerance of the phage endolysin-based candidate drug SAL200 after a single intravenous administration among healthy volunteers. Antimicrob. Agents Chemother. 2017, 24, 61. [CrossRef] [PubMed]

29. Cassino, C.; Murphy, M.; Boyle, J.; Rotolo, J.; Wittekind, M. Results of the first in human study of lysin CF-301 evaluating the safety, tolerability and pharmacokinetic profile in healthy volunteers. In Proceedings of the 26th European Congress of Clinical Microbiology and Infectious Diseases, Amsterdam, The Netherlands, 9-12 April 2016.

30. Sriram, B.; Chikkamadaiah, S.C.R.; Durgaiah, M.; Hariharan, S.; Jayaraman, R.; Kumar, S.; Maheshwari, U.; Nandish, P. Pharmacokinetics and efficacy of ectolysin P128 in a mouse model of systemic Methicillin resistant Staphylococcus aureus (MRSA) infection. In Proceedings of the ASM Microbe 2017, New Orleans, LA, USA, 1-5 June 2017.

31. Dufour, N.; Delattre, R.; Ricard, J.D.; Debarbieux, L. The lysis of pathogenic Escherichia coli by bacteriophages releases less endotoxin than betalactams. Clin. Infect. Dis. 2017, 64, 1582-1588. [CrossRef]

32. Fischetti, V.A. Bacteriophage endolysins: A novel anti-infective to control Gram-positive pathogens. Int. J. Med. Microbiol. 2010, 300, 357-362. [CrossRef]

33. Pires, D.P.; Cleto, S.; Sillankorva, S.; Azeredo, J.; Lu, T.K. Genetically engineered phages: A review of advances over the last decade. Microbiol. Mol. Biol. Rev. 2016, 80, 523-543. [CrossRef] [PubMed]

34. Roach, D.R.; Leung, C.Y.; Henry, M.; Morello, E.; Singh, D.; Di Santo, J.P.; Weitz, J.S.; Debarbieux, L. Synergy between the host immune system and bacteriophage is essential for successful phage therapy against an acute respiratory pathogen. Cell Host Microbe 2017, 22, 38-47.e4. [CrossRef] [PubMed]

35. Biswas, B.; Adhya, S.; Washart, P.; Paul, B.; Trostel, A.N.; Powell, B.; Carlton, R.; Merril, C.R. Bacteriophage therapy rescues mice bacteremic from a clinical isolate of vancomycin-resistant Enterococcus faecium. Infect. Immun. 2002, 70, 204-210. [CrossRef]

36. Fishman, M. Antibody formation in vitro. J. Exp. Med. 1961, 114, 837-856. [CrossRef] [PubMed]

37. Dabrowska, K.; Swita1a-Jelen, K.; Opolski, A.; Górski, A. Possible association between phages, Hoc protein, and the immune system. Arch. Virol. 2006, 151, 209-215. [CrossRef]

38. Belleghem, J.D.; Clement, F.; Merabishvili, M.; Lavigne, R.; Vaneechoutte, M. Pro- and anti-inflammatory responses of peripheral blood mononuclear cells induced by Staphylococcus aureus and Pseudomonas aeruginosa phages. Sci. Rep. 2017, 7, 8004. [CrossRef] [PubMed]

39. Majewska, J.; Beta, W.; Lecion, D.; Hodyra-Stefaniak, K.; Kłopot, A.; Kaźmierczak, Z.; Miernikiewicz, P.; Piotrowicz, A.; Ciekot, J.; Owczarek, B.; et al. Oral application of T4 phage induces weak antibody production in the gut and in the blood. Viruses 2015, 7, 4783-4799. [CrossRef] [PubMed]

40. Hodyra-Stefaniak, K.; Miernikiewicz, P.; Drapa, J.; Drab, M.; Jonczyk-Matysiak, E.; Lecion, D.; Kazmierczak, Z.; Beta, M.; Harhala, J.M.; Bubak, B.; et al. Mammalian host-versus-phage immune response determines phage fate in vivo. Sci. Rep. 2015, 5, 14802. [CrossRef] [PubMed]

41. Ochs, H.D.; Davis, S.D.; Wedgwood, R.J. Immunologic responses to bacteriophage phi-X 174 in immunodeficiency diseases. J. Clin. Investig. 1971, 50, 2559-2568. [CrossRef] [PubMed]

42. Smith, L.L.; Buckley, R.; Lugar, P. Diagnostic Immunization with Bacteriophage $\Phi$ X 174 in Patients with Common Variable Immunodeficiency/Hypogammaglobulinemia. Front. Immunol. 2014, 5, 410. [CrossRef] [PubMed] 
43. Oechslin, F. Resistance development to bacteriophages occurring during bacteriophage therapy. Viruses 2018, 10, 351. [CrossRef]

44. Jault, P.; Leclerc, T.; Jennes, S.; Pirnay, J.; Que, Y.A.; Resch, G.; Rousseau, A.F.; Ravat, F.; Carsin, H.; Floch, R.L.; et al. Efficacy and tolerability of a cocktail of bacteriophages to treat burn wounds infected by Pseudomonas aeruginosa (PhagoBurn): A randomised, controlled, double-blind phase 1/2 trial. Lancet Infect. Dis. 2019, 19, 35-45. [CrossRef]

45. Chang, R.Y.K.; Wallin, M.; Lin, Y.; Leung, S.S.Y.; Wang, H.; Morales, S.; Chan, H.K. Phage therapy for respiratory infections. Adv. Drug Deliv. Rev. 2018, 133, 76-86. [CrossRef]

46. Furfaro, L.L.; Payne, M.S.; Chang, B.J. Bacteriophage therapy: Clinical trials and regulatory hurdles. Front. Cell. Infect. Microbiol. 2018, 8, 376. [CrossRef]

47. Speck, P.; Smithyman, A. Safety and efficacy of phage therapy via the intravenous route. FEMS Microbiol. Lett. 2016, 363, 242. [CrossRef]

48. Jennes, S.; Merabishvili, M.; Soentjens, P.; Pang, K.W.; Rose, T.; Keersebilck, E.; Soete, O.; François, P.M.; Teodorescu, S.; Verween, G.; et al. Use of bacteriophages in the treatment of colistin-only-sensitive Pseudomonas aeruginosa septicaemia in a patient with acute kidney injury-A case report. Crit. Care 2017, 21, 129. [CrossRef] [PubMed]

49. Sula, L.; Sulova, J.; Stolcpartova, M. Therapy of experimental tuberculosis in guinea pigs with mycobacterial phages DS-6A, GR-21 T, My-327. Czech. Med. 1981, 4, 209-214. [PubMed]

50. Trigo, G.; Martins, T.G.; Fraga, A.G.; Longatto-Filho, A.; Castro, A.G.; Azeredo, J.; Pedrosa, J. Phage Therapy Is Effective against Infection by Mycobacterium ulcerans in a Murine Footpad Model. PLoS Negl. Trop. Dis. 2013, 7, 2183. [CrossRef] [PubMed]

51. Dedrick, R.M.; Guerrero-Bustamante, C.A.; Garlena, R.A.; Russell, D.A.; Ford, K.; Harris, K.; Gilmour, K.C.; Soothill, J.; Jacobs-Sera, D.; Schooley, R.T.; et al. Engineered bacteriophages for treatment of a patient with a disseminated drug-resistant Mycobacterium abscessus. Nat. Med. 2019, 25, 730-733. [CrossRef] [PubMed]

52. Pabary, R.; Singh, C.; Morales, S.; Bush, A.; Alshafi, K.; Bilton, D.; Alton, E.; Smithyman, A.; Davies, J. Anti pseudomonal bacteriophage reduces infective burden and inflammatory response in the murine lung. Antimicrob. Agents Chemother. 2016, 60, 744-751. [CrossRef] [PubMed]

53. Wang, Y.; Mi, Z.; Niu, W.; An, X.; Yuan, X.; Liu, H.; Li, L.; Liu, Y.; Feng, Y.; Huang, Y.; et al. Intranasal treatment with bacteriophage rescues mice from Acinetobacter baumannii-mediated pneumonia. Future Microbiol. 2016, 11, 631-641. [CrossRef]

54. Waters, E.M.; Neill, D.R.; Kaman, B.; Sahota, J.S.; Clokie, M.R.J.; Winstanley, C.; Kadioglu, A. Phage therapy is highly effective against chronic lung infections with Pseudomonas aeruginosa. Thorax 2017, 72, 666-667. [CrossRef]

55. Kutateladze, M.; Adamia, R. Phage therapy experience at the Eliava Institute. Médecine et Maladies Infectieuses 2008, 38, 426-430. [CrossRef]

56. Matinkhoo, S.; Lynch, K.; Dennis, J.; Finlay, W.; Vehring, R. Spray-dried respirable powders containing bacteriophages for the treatment of pulmonary infections. J. Pharm. Sci. 2011, 100, 5197-5205. [CrossRef]

57. Saussereau, E.; Vachier, I.; Chiron, R.; Godbert, B.; Sermet, I.; Dufour, N.; Pirnay, J.D.; De Vos, F.; Carrié, N.; Debarbieux, L. Effectiveness of bacteriophages in the sputum of cystic fibrosis patients. Clin. Microbiol. Infect. 2014, 20, 983-990. [CrossRef]

58. Ujmajuridze, A.; Chanishvili, N.; Goderdzishvili, M.; Leitner, L.; Mehnert, U.; Chkhotua, A.; Kessler, K.; Sybesma, W. Adapted Bacteriophages for Treating Urinary Tract Infections. Front. Microbiol. 2018, 9, 1832. [CrossRef] [PubMed]

59. Sarker, S.A.; Berger, B.; Deng, Y.; Kieser, S.; Foata, F.; Moine, D.; Descombes, P.; Sultana, S.; Huq, S.; Kumar-Bardhan, P.; et al. Oral application of Escherichia coli bacteriophage: Safety tests in healthy and diarrheal children from Bangladesh. Environ. Microbiol. 2016, 19, 237-250. [CrossRef] [PubMed]

60. Sarker, S.A.; Brüssow, H. From bench to bed and back again: Phage therapy of childhood Escherichia coli diarrhea. Ann. N. Y. Acad. Sci. 2016, 1372, 42-52. [CrossRef] [PubMed]

61. Ferry, T.; Leboucher, G.; Fevre, C.; Herry, Y.; Conrad, A.; Josse, J.; Batailler, C.; Chidiac, C.; Medina, M.; Lustig, S.; et al. Salvage Debridement, Antibiotics and Implant Retention ("DAIR") with local injection of a selected cocktail of bacteriophages: Is it an option for an elderly patient with relapsing Staphylococcus aureus prosthetic-joint infection? Open Forum Infect. Dis. 2018, 24, 5. [CrossRef] [PubMed] 
62. Akanda, Z.Z.; Taha, M.; Abdelbary, H. Current review-The rise of bacteriophage as a unique therapeutic platform in treating peri-prosthetic joint infections. J. Orthop. Res. 2017, 36, 1051-1060. [CrossRef] [PubMed]

63. Rhoads, D.D.; Wolcott, R.D.; Kuskowski, M.A.; Wolcott, B.M.; Ward, L.S.; Sulakvelidze, A. Bacteriophage therapy of venous leg ulcers in humans: Results of a phase I safety trial. J. Wound Care 2009, 238, 240-243. [CrossRef]

64. Rose, T.; Verbeken, G.; De Vos, D.; Merabishvili, M.; Vaneechoutte, M.; Lavigne, R.; Jennes, S.; Zizi, M.; Pirnay, J.P. Experimental phage therapy of burn wound infection: difficult first steps. Int. J. Burns Trauma 2014, 4, 66-73. [PubMed]

65. Wright, A.; Hawkins, C.H.; Anggard, E.E.; Harper, D.R. A controlled clinical trial of a therapeutic phage preparation in chronic otitis due to antibiotic-resistant Pseudomonas aeruginosa; a preliminary report of efficacy. Clin. Otolaryngol. 2009, 34, 349-357. [CrossRef]

66. Yoichi, M.; Abe, M.; Miyanaga, K.; Unno, H.; Tanji, Y. Alteration of tail fiber protein gp38 enables T2 phage to infect Escherichia coli O157: H7. J. Biotechnol. 2005, 115, 101-107. [CrossRef]

67. Mahichi, F.; Synnott, A.J.; Yamamichi, K.; Osada, T.; Tanji, Y. Site-specific recombination of T2 phage using IP008 long tail fiber genes provides a targeted method for expanding host range while retaining lytic activity. FEMS Microbiol. Lett. 2009, 295, 211-217. [CrossRef]

68. Lin, T.-Y.; Lo, Y.-H.; Tseng, P.-W.; Chang, S.-F.; Lin, Y.-T.; Chen, T.-S. A T3 and T7 recombinant phage acquires efficient adsorption and a broader host range. PLoS ONE 2012, 7, e30954. [CrossRef] [PubMed]

69. Bikard, D.; Euler, C.W.; Jiang, W.; Nussenzweig, P.M.; Goldberg, G.W.; Duportet, X.; Fischetti, V.A.; Marraffini, L.A. Exploiting CRISPR-Cas nucleases to produce sequence-specific antimicrobials. Nature Biotechnol. 2014, 32, 1146. [CrossRef]

70. Citorik, R.J.; Mimee, M.; Lu, T.K. Sequence-specific antimicrobials using efficiently delivered RNA-guided nucleases. Nature Biotechnol. 2014, 32, 1141. [CrossRef] [PubMed]

71. Pei, R.; Lamas-Samanamud, G.R. Inhibition of biofilm formation by T7 bacteriophages producing quorum quenching enzymes. Appl. Environ. Microbiol. 2014, 80, 5340-5348. [CrossRef] [PubMed]

72. Lu, T.K.; Collins, J.J. Dispersing biofilms with engineered enzymatic bacteriophage. Proc. Natl. Acad. Sci. USA 2007, 104, 11197-11202. [CrossRef] [PubMed]

73. Vitiello, C.L.; Merril, C.R.; Adhya, S. An amino acid substitution in a capsid protein enhances phage survival in the mouse circulatory system more than a 1000-fold. Virus Res. 2005, 114, 101-103. [CrossRef] [PubMed]

74. Merril, C.R.; Biswas, B.; Carlton, R.; Jensen, N.C.; Creed, G.J.; Zullo, S.; Adhya, S. Long-circulating bacteriophage as antibacterial agents. Proc. Natl. Acad. Sci. USA 1996, 93, 3188-3192. [CrossRef] [PubMed]

75. Hagens, S.; Habel, A.; Von Ahsen, U.; Von Gabain, A.; Bläsi, U. Therapy of experimental Pseudomonas infections with a nonreplicating genetically modified phage. Antimicrob. Agents Chemother. 2004, 48, 3817-3822. [CrossRef]

76. Matsuda, T.; Freeman, T.A.; Hilbert, D.W.; Duff, M.; Fuortes, M.; Stapleton, P.P.; Daly, J.M. Lysis-deficient bacteriophage therapy decreases endotoxin and inflammatory mediator release and improves survival in a murine peritonitis model. Surgery 2005, 137, 639-646. [CrossRef]

77. Fauconnier, A. Regulating phage therapy: The biological master file concept could help to overcome the regulatory challenge of personalized medicines. EMBO Rep. 2017, 18, 198-200. [CrossRef]

78. Kutter, E.; De Vos, D.; Gvasalia, G.; Alavidze, Z.; Gogokhia, L.; Kuhl, S.; Abedon, S.T. Bacteriophage therapy of venous leg ulcers in humans: Results of a phase I safety trial. Curr. Pharm. Biotechnol. 2010, 11, 69-86. [CrossRef] [PubMed]

79. Commission de la santé publique, de l'environnement et du renouveau de la société. Questions jointes de Mme Muriel Gerkenset, M. Philippe Blanchart àlaministredes Affaires sociales et de la Santé publiques ur'la phagothérapie' àla ministre des Affaires sociales et de la Santé publique' (N 11955 and N 12911). 2016. Available online: https://www.dekamer.be/doc/CCRA/pdf/54/ac464.pdf (accessed on 1 August 2019).

80. El-Shibiny, A.; El-Sahhar, S. Bacteriophages: The possible solution to treat infections caused by pathogenic bacteria. Can. J. Microbiol. 2017, 63, 865-879. [CrossRef] [PubMed]

81. Golkar, Z.; Bagasra, O.; Pace, D.G. Bacteriophage therapy: A potential solution for the antibiotic resistance crisis. J. Infect. Dev. Ctries. 2014, 8, 129-136. [CrossRef] [PubMed]

82. Wittebole, X.; De Roock, S.; Opal, S.M. A historical overview of bacteriophage therapy as an alternative to antibiotics for the treatment of bacterial pathogens. Virulence 2014, 5, 226-235. [CrossRef] [PubMed] 
83. Azeredo, J.; Sutherland, I.W. The use of phages for the removal of infectious biofilms. Cur. Pharm. Biotechnol. 2008, 9, 261-266. [CrossRef]

84. Anon. When is an allergy to an antibiotic really an allergy? Best Pract. J. 2015, 68, 22.

85. Terico, A.T.; Gallagher, J.C. Beta-lactam hypersensitivity and cross-reactivity. J. Pharm. Pract. 2014, 27, 530-544. [CrossRef] [PubMed]

86. Ligonenko, O.V.; Borysenko, M.M.; Digtyar, I.I.; Ivashchenko, D.M.; Zubakha, A.B.; Chorna, I.O.; Shumeyko, I.A.; Storozhenko, O.V.; Gorb, L.I.; Ligonenko, O.O. Application of bacteriophages in complex of treatment of a shot-gun wounds of soft tissues in the patients, suffering multiple allergy for antibiotics. Klin. Khir. 2015, 10, 65-66.

87. Ghannad, M.S.; Mohammadi, A. Bacteriophage: Time to re-evaluate the potential of phage therapy as a promising agent to control multidrug-resistant bacteria. Iran. J. Basic Med. Sci. 2012, 15, 693-701.

88. Kucharewicz-Krukowsk, A.; Slopek, S. Immunogenic effect of bacteriophage in patients subjected to phage therapy. Arch. Immunol. Ther. Exp. (Warsz.) 1987, 35, 553-561.

(C) 2019 by the authors. Licensee MDPI, Basel, Switzerland. This article is an open access article distributed under the terms and conditions of the Creative Commons Attribution (CC BY) license (http://creativecommons.org/licenses/by/4.0/). 